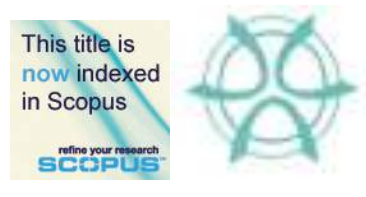

PLANNING MALAYSIA:

Journal of the Malaysian Institute of Planners

SPECIAL ISSUE IV (2016), Page 263 - 272

\title{
IDENTIFY SIGNIFICANT INDICATORS FOR A HAPPY CITY
}

\author{
Hamed Mirzaei ${ }^{1}$, Azin Bahreini ${ }^{2}$, Mehdi Moeinaddini ${ }^{3}$, Zohreh Asadi-Shekari ${ }^{4}$, \\ Muhammad Zaly Shah $^{5}$ \& Zahid Sultan ${ }^{6}$ \\ 1,2,3,4,5,6 Faculty of Built Environment \\ UNIVERSITI TEKNOLOGI MALAYSIA
}

\begin{abstract}
Although, happiness has been evaluated by many researchers, there are very limited studies on happy environment, specifically happy cities. In addition, different methods that have been introduced for measuring happiness by previous studies have several major shortcomings. Firstly, happiness is considered equivalent to satisfaction or the quality of life. Secondly, the majority of these methods are not easy to follow and it is difficult to connect them to design process. Furthermore, these methods support only a limited number of indicators and majority of them are not related to the happy environment. Thus, this paper reviews prominent studies on happiness evaluations and happy environment to identify effective indicators for happy cities. It also attempts to highlight current happiness evaluation methods that consider happy environment to determine how various studies assess cities for happiness. The weaknesses and strengths of different evaluation methods are discussed in this paper to propose a better way to assess happy cities. A systematic review is used to identify indicators for happy cities. Overall, socio-economic factors, environmental factors (e.g., air pollution and temperature), geographical location and facilities management are effective variables for happy cities. This study discusses the challenges in happiness evaluation and attempts to introduce new objectives for futures studies. The results of this study can be used to propose strategies to have happier cities.
\end{abstract}

Keyword: Happiness; Happy city; Happy environment; Measuring happiness

\section{INTRODUCTION}

Nowadays people who are living in urban areas suffer from stress and depression because of their motorized lifestyle (Bókony et al., 2012; Peig and Green, 2010). Although happiness can decrease this stress and stress-related diseases (Shochat et al., 2007; Ã-Ralf et al., 2007), people who are living in urban areas are not as happy as people who are living close to nature. Lack of happiness has negative effects on the quality of life (Mercer, 2012; Ballas, 2013). In addition to the birth or genetics, marital status and earnings, environmental factors such as air quality, green space, temperature, wind speed and ambient noise level also can affect happiness level (Peig and Green, 2010; ̃̂-Ralf et al., 2007; Jordison and Kieran, 2003). Therefore, paying attention to the environmental factors in urban areas can affect happiness and quality of life. 
Dense urban living has been prescribed as a solution for sprawl negative externalities such as environmental and resources crisis. However, this solution changes the society rapidly and affects lifestyle and the quality of life (Huang et al., 2013). If enough attentions would not been paid to the lifestyle changes, the resulted lifestyle can decrease happiness and increase stress and pressure (Mecer, 2012). Therefore, one of the problems in our cities can be lack of happiness feeling while people experience more stress and pressure and this issue can affect the quality of life (Bókony et al., 2012).

Researchers use various models for measuring the happiness (Savageau, 2007; Ballas, 2013). For instance, some studies measure the happiness using the effective factors for quality of life (Marans and Stimson, 2011). Well-being is also one of the important factors that represents happiness in many studies (e.g., Gowdy, 2005; Dolan et al., 2008; Welsch, 2009). Satisfaction (e.g. Mackerron and Mourato, 2009; Menz and Walsch, 2010) and pleasure (e.g. Maddison and Rehdanz, 2010; Raphael et al., 2001) also represent happiness in various studies. The living environment can affect all of these factors that are used to measure happiness. Therefore, there is a possible relationship between living environment and happiness (Ballas \& Dorling, 2013).

There are some studies that consider the relationship between happiness and environment (Marshall et al., 2014). These limited studies (e.g., Susana Ferreira et al., 2010; Tobias Menz, 2011) focused on the relationship between macro-level factors such as air pollution, economic and life satisfaction at country level (Ballas \& Dorling, 2013; Welsch, 2009; Ballas \& Dorling, 2007). Therefore, this study tries to focus on city level that has not been investigated.

\section{METHOD}

Happiness can be affected by everything that people need such as income, health, recreational activities and etc (Dolan et al., 2008). M.Farouk Radwan (2014) believes that happiness is the feeling that you experience when you realize that everything is exactly as should be. Happiness comes from everything around you that can give satisfaction or pleasure feeling to you (Susana Ferreira et al., 2010). Cities that are living places for lots of people contain everything around people's life. Therefore, cities can affect people's happiness.

There are various measurements for happiness in different studies. These measurements include satisfaction (e.g. Mackerron and Mourato, 2009; Menz and Welsch, 2011), quality of life (Marans and Stimson, 2011), well-being (e.g., Gowdy, 2005; Dolan et al., 2008; Welsch, 2009), and pleasure (e.g. Maddison and Rehdanz, 2010; Raphael et al., 2001). In addition, there are some indicators in the cities that can affect satisfaction, quality of life, well-being and pleasure. Therefore, happy city factors can be achieved by considering the relationship between happiness measurements and city indicators. The happy city factors and their effects are evaluated in this study by reviewing existing limited studies about happiness and urban life. This paper tries to review the majority of the studies that considered at least one of the happiness measurements and urban structures indicators.

Although age, gender and race in addition to the socio-economic factors such as income and cultural differences can affect happiness, the current study considers just urban structure indicators regardless of the individual characteristics. Therefore, this study focuses on urban structure indicators that are the same in various socio-economic 
contexts. Therefore, the results can be used for various cities around the world. This study also considers happy city factors that can be defined by measurable factors and the influence of non-measureable indicators (e.g., sense of belonging) is not considered.

\section{RESULTS}

Economic is one of the factors that have considerable effects on happiness level and wellbeing (Welsch and Kühling, 2009). Various studies have focused on subjective well-being because they can measure and compare well-being between people. Hereby, they achieved their desired information by asking people. In addition, they fitted econometric models to their respondents and assess some of happiness factors empirically.

Dolan et al. (2008) determined factors that have positive or negative correlations with well-being. The positive factors include environmental condition (e.g. green space, blue space, attractive land cover and etc), high income, ambition and social capital indicators (e.g., trust, membership of friendly relations or interest groups and belief in a god). The negative factors include environmental problems (e.g. air pollution, noise pollution, water pollution and etc), higher incomes for others, unemployment, higher past income and negative relationship indicators (such as separation and divorce). In addition, economists found a new way to measure happiness by the influence of environmental factors on well-being and monetary terms (Welsch, 2009). Welsch (2006) found links between environment and income through computing the cost of air pollution (e.g., healthcare and material repairing costs). Lower cost means more monetary benefits and being happier. The positive and negative environmental factors that are mentioned in these studies can be used as parts of our proposed happy city indicators.

The landscape is one of the environmental factors that can affect happiness by creating evolutionary kind of feeling (Searns, 1995; Milligan et al., 2004). Hartig et al. (2010) focused on the living environment around people that can shape the human mind. This study mentioned that the nature of human always depends on the nature. Therefore, attractive landscape can create pleasure and happiness feeling that has positive effects on mind. Various studies have tried to prove that nature improve emotional needs such as happiness (Wilson, 1993; Katsui and Ghotbi, 2005). In addition to the positive effects of natural environments on emotion and happiness, they also act as restoration of psychological (Wilson, 1993; Aks \& Sprott, 1996; Katsui and Ghotbi, 2005; Hartig et al., 2010). The natural environments (e.g., landscape, forest, savanna and mountains) should be reachable in the environment around human habitat. Diener et al. (2009) and Moro et al. (2008) found that people (based on the subjective well-being) who are living proximity to the coastline are happier. Ferreira \& Moro (2010) mentioned that coastline is not significant factor for happiness if the distance is more than $5 \mathrm{~km}$.

Paying attention to the natural forms for landscape is important since natural habitats have curve, regular and irregular geometric shapes that lead to increase aesthetic, positive emotion and pleasure (Aks \& Sprott, 1996; Jordison and Kieran 2003). The natural capital is one of environmental factors in various studies that has positive relationship with happiness indicators at country level (Engelbrecht, 2009; Vemuri and Costanza 2006; Engelbrecht 2009). This factor also can be used at the city level.

Frijters and Praag (1998) investigated on the weather's factors and influences on the subjective well-being (SWB) in Russia. They focused on temperature between 18.3 $\mathrm{Co}$ and $28 \mathrm{Co}$, precipitation, wind speed, rainy days and hours of sunshine. They found 
that these factors can affect SWB. For instance, the temperature more than 28 Co or less than 18.3 Co has negative effect on SWB. Rehdanz and Maddison (2005) also examined climate variables and focused on variations in temperature and months (e.g., lower temperature at warm months and higher temperature at cool months). They found that SWB is related to mean temperature variations. Similarly, Maddison and Rehdanz (2010) focused on temperature and determined ideal temperature using data in country level (87 countries). The proposed ideal temperature is between $18.3 \mathrm{Co}$ and $28 \mathrm{Co}$. The effects of precipitation, wind speed, rainy days and hours of sunshine on SWB can be different based on the study area. For instance, wind has negative effect on SWB in Ireland (Moro et al., 2008; Ferreira and Moro, 2010).

Welsch $(2002 ; 2003 ; 2006 ; 2007)$ found a negative relationship between SWB and air pollution factors at country level. Menz and Welsch (2010) also introduced the negative effects of air pollution on the health that decrease SWB using data from 25 countries. They mentioned that if the concentration of air pollution is more than PM10, it can lead to health problems and decrease SWB. Similarly, Rehdanz and Maddison (2005, 2008) found a relationship between SWB and perceived of participants regarding air pollution level (higher perceived pollution level, lower SWB). There are considerable studies regarding the negative effects of air pollution on SWB and happiness at country level (e.g., Ferreira and Moro, 2010; MacKerron and Mourato, 2009; Levinson, 2009). This factor also can be used at the city level.

Water pollution also can affect SWB and happiness. Part of the water pollution can be related to air pollution but the main reasons are organic pollutants (e.g., severely polluted sources that are located near the rivers). Water pollution can increase people worries regarding drinking water in their house, health problems and losing natural resources such as green and open space. Therefore, water pollution is another environmental factors that have direct negative effect on individuals' well-being, life satisfaction and happiness (Israel and Levinson, 2003; Ferreira and Moro, 2010). Van Praag and Baarsma (2005) focused on noise pollution and examined aircraft noise near airport in Amsterdam. They found a negative correlation between noise pollution and SWB. Weinhold (2008) investigated the effect of perceived noise pollution on SWB using individual data in Europe (e.g., the sound of aircraft when they slept). This study also found a strong negative relationship. Table 1 summarizes the effective factors regarding happiness and built environment that are mentioned by previous studies. This table also shows the relationship between built environment factors and happiness. These factors can be used to define happy city indicators.

\section{ENVIRONMENTAL HEALTH INDICATORS}

Indicators are measurements selected to represent a large phenomenon of interest. An indicator points to certain issue or certain condition in certain city. It provides useful information for decision makers, not just data (Peterson et al., 1999), and can generate discussion among people with different backgrounds and viewpoints (Andrew, 1998).

Environmental indicators evolved during the 1970s when the environment became a mainstream issue and governments responded with environmental assessment legislation and processes. In the 1980s, two approaches arrived, which were sustainable development and healthy communities. Sustainable development indicators are now commonly used at the national, regional and local levels in many nations. The healthy 
community model continues to frame analysis, although it seems to have been eclipsed since the late 1990s by the quality of life model (Seasons, 2005). In the past 20 years, some of the most interesting theoretical advances in broad-based indicator development have been the promotion of a capabilities approach; the synthesis of economic, quality of life and environmental indicators under the banner of sustainability; and experimentation with participatory methodologies (Keough, 2005).

Besides the broad-based sustainable indicators and quality of life indicators, there are also more specified or focused indicators which have been developed and used for the issues of environmental health, such as Environmental Health Indicator by WHO, the adaptation by WHO-Europe and New Zealand, and the Environmental Public Health Indicators by Atlanta.

In this study, preliminary set of environmental health indicators was developed for the aspect of urban air. It includes two major components which are air quality indicators and air-related health indicators. In selecting and proposing environmental health indicators, the following points were taken into consideration:

Table 1: Summary of significant environment factors that influence on happiness

\begin{tabular}{|c|c|c|c|c|c|c|c|c|c|c|c|}
\hline & 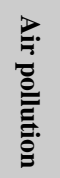 & 总 & 章 & 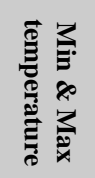 & 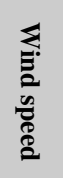 & 胥. & $\stackrel{\mathscr{E}}{E}$ & 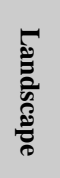 & 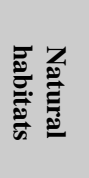 & 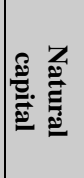 & 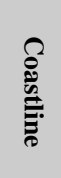 \\
\hline $\begin{array}{l}\text { Aks \& } \\
\text { Sprott, } \\
(1996) \\
\end{array}$ & & & & & & & & & + & & \\
\hline $\begin{array}{l}\text { Brereton et } \\
\text { al. }(2008)\end{array}$ & & & & & & & & & & & + \\
\hline $\begin{array}{l}\text { Engelbrecht } \\
\text { (2009) }\end{array}$ & & & & & & & & & & + & \\
\hline $\begin{array}{l}\text { Ferreira } \\
\text { and moro } \\
(2010)\end{array}$ & - & & - &,-+ &,-+ &,-+ &,-+ & & & & + \\
\hline $\begin{array}{l}\text { Frijters and } \\
\text { Praag } \\
(1998)\end{array}$ & & & &,-+ & & & & & & & \\
\hline $\begin{array}{l}\text { Hartig et al. } \\
(2010)\end{array}$ & & & - & & & & & + & & & \\
\hline $\begin{array}{l}\text { Israel and } \\
\text { Levinson, } \\
2003\end{array}$ & & & & & & & & & & & \\
\hline $\begin{array}{l}\text { Juricevic et } \\
\text { al (2010) }\end{array}$ & & & & & & & & & + & & \\
\hline $\begin{array}{l}\text { Katsui and } \\
\text { Ghotbi } \\
(2012)\end{array}$ & & & & & & & & & + & & \\
\hline $\begin{array}{l}\text { Levinson } \\
(2009)\end{array}$ & - & & & & & & & & & & \\
\hline $\begin{array}{l}\text { Mackerron } \\
\text { and } \\
\text { Mourato } \\
(2009)\end{array}$ & - & & & & & & & & & & \\
\hline
\end{tabular}


Hamed Mirzaei, Azin Bahreini, Mehdi Moeinaddini, Zohreh Asadi-Shekari, Muhammad Zaly Shah \& Zahid Sultan Identify Significant Indicators for a Happy City

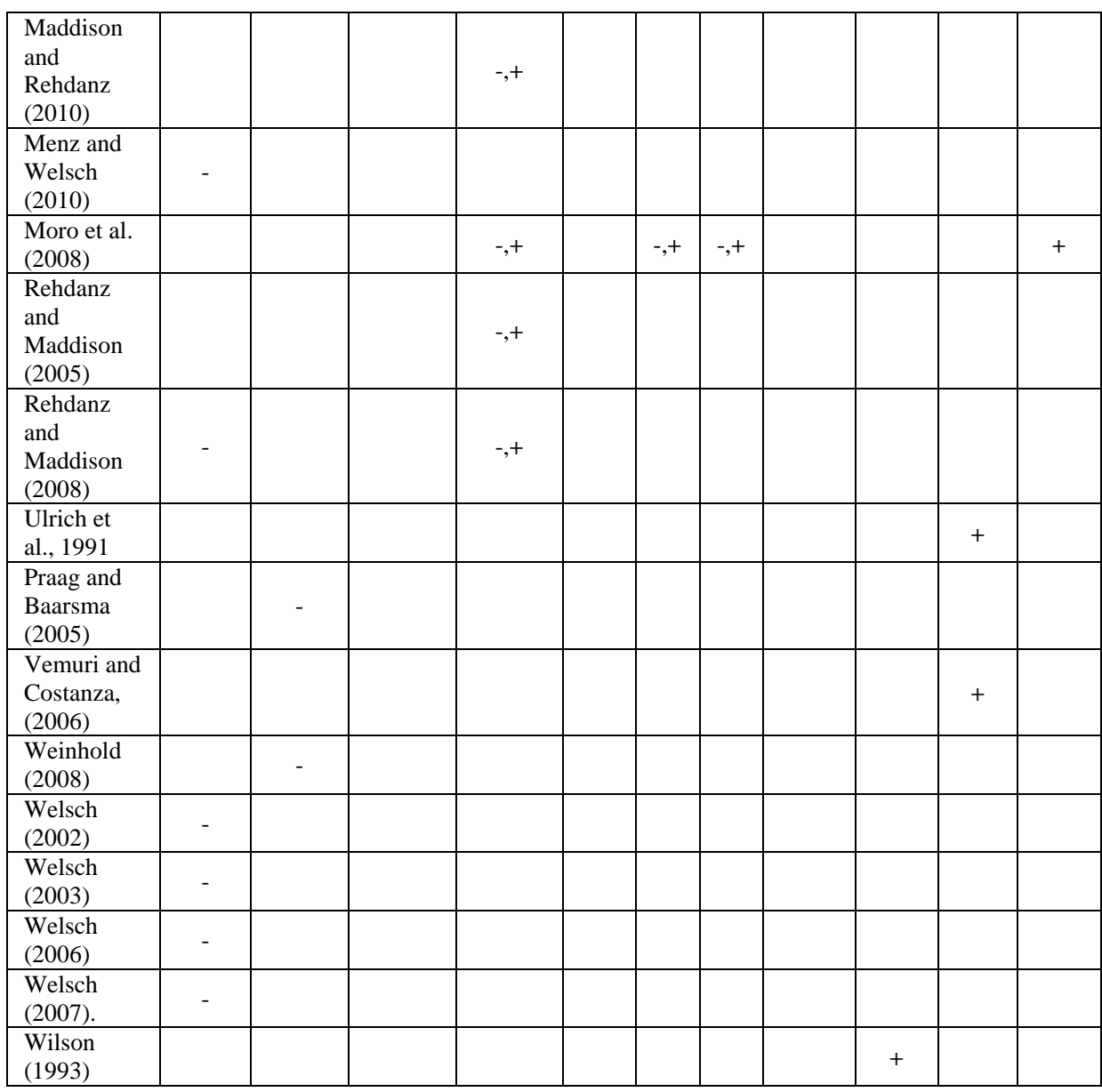

Note:

(-) negative effects on happiness

$(+)$ positive effects on happiness

\section{CONCLUSION}

Increase urbanization and motorized lifestyle lead to various negative externalities such as inactive lifestyle, traffic congestions, air pollution, more fuel consumption, noise pollution and health problem. These negative externalities can reduce happiness in our living environment. Nowadays, living environments especially in developing countries are not happy environments. There are limited studies regarding happy environment especially at city level. Therefore, this study focuses on the happy cities and tries to find happy city factors by reviewing current literature. The results show that although socioeconomic factors affect happiness significantly, environmental factors such as air quality, climate, noise and access to green spaces also can affect happiness.

Based on previous studies, there are different evidences from observational and experimental sources that showing some environmental factors have positive correlation 
with SWB and happiness (e.g., landscape, natural habitats and capital, coastline, temperature between 18.3 co and $28 \mathrm{co}$ ) while the effects of some of them such as wind speed, rainy or sunny days are highly depend on the weather conditions in the region. There are also some environmental factors such as air pollution, noise pollution, water pollution and temperature less than 18.3 co and more than 28 co that have negative correlation with SBW and happiness.

Because happiness is an essential need, appropriate conditions in the cities can increase happiness. However, previous studies did not consider cities opportunities to increase happiness. The current study attempts to make up for this shortcoming by introducing some factors for happy cities. These indicators were extracted from limited existing literature. The value of this research is in providing a foundation to develop happy city studies that were not addressed previously.

Although this study tries to cover majority of limited studies regarding built environment and happiness, further studies can introduce more factors for happy city by considering more studies and including experts and people opinions. Further studies also can prioritize the happy city factors based on the strength of their relationship with happiness. A model to evaluate and rate cities for happiness also can be proposed by further studies. This model can be developed based on the relationships between happy city factors and happiness. The final step for further studies can be suggesting improvements to have happier cities based on the failures that are identified by their proposed model.

\section{ACKNOWLEDGMENT}

The authors wish to thank all of those who have supported this research for their useful comments during its completion. In particular, we would like to acknowledge the Universiti Teknologi Malaysia Research Management Centre (RMC) and Centre for Innovative Planning and Development (CIPD). The funding for this project is made possible through the research grant obtained from the Ministry of Education, Malaysia under the Fundamental Research Grant Scheme (FRGS) 2014 (FRGS grant no:R.J130000.7821.4F602). 
Hamed Mirzaei, Azin Bahreini, Mehdi Moeinaddini, Zohreh Asadi-Shekari, Muhammad Zaly Shah \& Zahid Sultan Identify Significant Indicators for a Happy City

\section{REFERENCES}

Aks, D. J. \& Sprott, J. C. 1996. Quantifying aesthetic preference for chaotic patterns. Empirical studies of the arts, 14(1), 1-16. 57

Ã, R. H., Hug, S., \& Seeland, K. 2007. Restoration and stress relief through physical activities in forests and parks, 6, 213-225. http://doi.org/10.1016/j.ufug.2007.08.004

Ballas, D., \& Dorling, D. 2007. Measuring the impact of major life events upon happiness. International Journal of Epidemiology, 36, 1244-1252.

Ballas, D., \& Dorling, D. 2013. The geography of happiness. In S. David, I. Boniwell, \& A. Conley Ayers (Eds.), The Oxford handbook of happiness (pp. 465-481). Oxford University Press.

Bókony, V., Seress, G., Nagy, S., Lendvai, Á. Z., \& Liker, A. 2012. Multiple indices of body condition reveal no negative effect of urbanization in adult house sparrows. Landscape and Urban Planning, 104(1), 75-84. http://doi.org/10.1016/j.landurbplan- .2011.10.006

Diener, E., Lucas, R. E., Schimmack, U., \& Helliwell, J. F. 2009. Well-being for public policy. New York: Oxford University Press USA. 21, 45, 53

Diener, E. \& Seligman, M. E. P. 2004. Beyond money: Toward an economy of well-being. Psychological Science in the Public Interest, 5(1), 1-31. 45

Dolan, P., Peasgood, T., \& White, M. 2008. Do we really know what makes us happy? A review of the economic literature on the factors associated with subjective wellbeing. Journal of Economic Psychology, 29, 94-122. 20, 48, 50

Engelbrecht, H. 2009. Natural capital, subjective well-being, and the new welfare economics of sustainability: Some evidence from cross country regressions. Ecological Economics, 69(2), 380-388. 61, 62

Ferreira, S. \& Moro, M. 2010. On the use of subjective well-being data for environmental valuation. Environmental and Resource Economics, 46(3), 249-273. 20, 21, 40, 41, 42, 43, 60, 61, 62, 129, 153, 154

Frijters, P. \& Praag, B. M. S. V. 1998. The effects of climate on welfare and well-being in Russia. Climatic Change, 39, 61-81. 60

Gowdy, J. 2005. Toward a new welfare economics for sustainability. Ecological Economics, 53(2), 211-222. http://doi.org/10.1016/j.ecolecon.2004.08.007

Hartig, T., van den Berg, A., Hagerhall, C. M., Tomalak, M., Bauer, N., Hansmann, R., Ojala, A., Syngollitou, E., Carrus, G., van Herzele, A., Bell, S., Podesta, M. T. C., \& Waseth, G. 2010. Health benefits of nature experience: Psychological, social and cultural processes. In K. Nilsson, M. Sangster, C. Gallis, T. Hartig, S. de Vries, K. Seeland, \& J. Schipperijn (Eds.), Forests, Trees and Human Health. Springer. 56, 57

Hektner, J. M., Schmidt, J. A., \& Csíkszentmihályi, M. 2007. Experience Sampling Method: Measuring the Quality of Everyday Life. London: Sage. 14, 33, 63, 83, $84,85,88$

Huang, Y. L. \& Batterman, S. 2000. Residence location as a measure of environmental exposure:A review of air pollution epidemiology studies. Journal of Exposure Analysis and Environmental Epidemiology, 10(1), 66-85. 62 
Israel, D. \& Levinson, A. 2003. Examining the relationship between household satisfaction and pollution. Paper presented at the Eastern Economics Association Meetings, 23 February 2003.61

Jordison, S., \& Kieran, D. 2003. Crap towns: The 50 worst places to live in the UK. Boxtree.

Juricevic, I., Land, L., Wilkins, A., \& Webster, M. A. 2010. Visual discomfort and natural image statistics. Perception, 39(7), 884-899. 57

Katsui, Y., \& Ghotbi, N. 2005. COMMENTARY: Biophilia for happiness and environmental ethics.

Kahneman, D., Krueger, A. B., Schkade, D. A., Schwarz, N., \& Stone, A. A. 2004b. A survey method for characterizing daily life experience: The Day Reconstruction Method. Science, 306(5702), 1776-1780. 33, 63

Levinson, A. 2009. Valuing public goods using happiness data: The case of air quality. Working Paper 15156, National Bureau of Economic Research, Cambridge, Massachusetts. 60214

MacKerron, G. \& Mourato, S. 2009. Life satisfaction and air quality in London. Ecological Economics, 68, 1441-1453. 23, 39, 47, 60, 62, 157, 158

Maddison, D. \& Rehdanz, K. 2010. The impact of climate on life satisfaction. Working Paper 1658, Kiel Institute for the World Economy. 58, 60

Marans, RW., \& Kweon, B. 2011. The QoL in metro detroit at the beginning of the millenium. In R. W. Marans \& R. J. Stimson (Eds.), Investigating quality of urban life (pp. 163-184). Dodrecht: Springer.

Marans, RW., \& Stimson, RJ. (Eds.). 2011. Investigating quality of urban life. Dodrecht: Springer.

Menz, T. \&Welsch, H. 2010. Population aging and environmental in OECD countries. The case of air pollution. Ecological Economics, 69(12), 2582-2589. 60, 61

Mercer. 2012. Quality of Living worldwide city rankings - Mercer survey. Mercer. <http://uk.mercer.com/press-releases/quality-of-living-report-2012>.

Milligan, C., Gatrell, A., \& Bingley, A. 2004. "Cultivating health”: Therapeutic landscapes and older people in northern England. Social Science and Medicine, 58(9), 1781-1793. http://doi.org/10.1016/S0277-9536(03)00397-6

M.Farouk Radwan. The Psychology of Attraction Explained: Understand what attracts people to each other. CreateSpace Independent Publishing Platform (4 Sept. 2014).

Moro, M., Brereton, F., Ferreira, S., \& Clinch, J. P. 2008. Ranking quality of life using subjective well-being data. Ecological Economics, 65, 448-460. 36, 43, 60, 61, 62

Peig, J., \& Green, A. J. 2010. The paradigm of body condition : a critical reappraisal of current methods based on mass and length, 1323-1332. http://doi.org/10.1111/j.1365-2435.2010.01751.

Rehdanz, K. 2007. Species diversity and human well-being: A spatial econometric approach. Working Paper FNU-151, Sustainability and Global Change Research Unit, Hamburg University and Centre for Marine and Atmospheric Science, Hamburg. 39, 43, 54, 61, 62, 199

Rehdanz, K. \& Maddison, D. 2005. Climate and happiness. Ecological Economics, 52(1), 25-111. 28, 60, 61 
Hamed Mirzaei, Azin Bahreini, Mehdi Moeinaddini, Zohreh Asadi-Shekari, Muhammad Zaly Shah \& Zahid Sultan Identify Significant Indicators for a Happy City

Rehdanz, K. \& Maddison, D. 2008. Local environmental quality and life-satisfaction in Germany. Ecological Economics, 64, 787-797. 47, 60

Savageau, D. 2007. Places rated Almanac. Washington, DC: Places Rated Books LLC.

Searns, R. M. 1995. The evolution of greenways as an adaptive urban landscape form. Landscape and Urban Planning, 33(1-3), 65-80. http://doi.org/10.1016/01692046(94)02014-7

Shiffman, S., Stone, A. A., \& Hufford, M. R. 2008. Ecological Momentary Assessment. Clinical Psychology, 4(1), 1-32. 33, 63

Shochat, E., Warren, P. S., Faeth, S. H., Mcintyre, N. E., \& Hope, D. 2007. From patterns to emerging processes in mechanistic urban ecology, 21(4). http://doi.org/10.1016/j.tree.2005.11.019

Ulrich, R. S., Simons, R. F., Losito, B. D., Fiorito, E., Miles, M. A., \& Zelson, M. 1991. Stress recovery during exposure to natural and urban environments. Journal of Environmental Psychology, 11(3), 201-230. 57

Van Praag, B. M. S. \& Baarsma, B. E. 2005. Using happiness surveys to value intangibles: The case of airport noise. The Economic Journal, 115, 224-246. 41, 47, 61, 156

Vemuri, A. W. \& Costanza, R. 2006. The role of human, social, built, and natural capital in explaining life satisfaction at the country level: Toward a National Well-Being Index (NWI). Ecological Economics, 58(1), 119-133. 61

Weinhold, D. 2008. How big a problem is noise pollution? A brief happiness analysis by a perturbable economist. Working paper. Available from: http://personal.lse.ac.uk/weinhold/The\%20utility\%20costs\% 20of\%20noise\%20pollutionv4.pdf [cited 11 December 2009]. 61

Welsch, H. 2002. Preferences over prosperity and pollution: Environmental valuation based on happiness surveys. Kyklos, 55(4), 473-494. 21, 36, 60, 62

Welsch, H.2003. Environment and happiness: Valuation of air pollution in ten European countries. German Institute for Economic Research (DIW), Berlin. Available from: http://www.diw.de/deutsch/produkte/ publikationen/diskussionspapiere/ docs/papers/dp356.pdf [cited 25 April 2007]. 60, 62

Welsch, H. 2006. Environment and happiness: Valuation of air pollution using life satisfaction data. Ecological Economics, 58, 801-813. 58, 60, 62

Welsch, H. 2007. Environmental welfare analysis: A life satisfaction approach. Ecological Economics, 62(3-4), 544-551. 47, 60, 62

Welsch, H. 2009. Implications of happiness research for environmental economics. Ecological Economics, 68(11), 2735-2742. 20, 43, 46, 83

Welsch, H. \& Kühling, J. 2009. Using happiness data for environmental valuation: Issues and applications.

Wilson, E. O. 1993. Biophilia and the conservation ethic. In S. R. Kellert \& E. O. Wilson (Eds.), The Biophilia Hypothesis (pp. 31-41). Washington DC: Island Press. 56 